\title{
Exploring the quality of pre-service teachers' critical analysis of cartoons within environmental contexts in the Life Sciences
}

\begin{tabular}{|c|c|}
\hline \multicolumn{2}{|c|}{$\begin{array}{l}\text { Authors: } \\
\text { Rajendran P. Pillay }{ }^{1} \text { (1) } \\
\text { Samantha Govender }{ }^{2} \text { (1) }\end{array}$} \\
\hline \multicolumn{2}{|c|}{$\begin{array}{l}\text { Affiliations: } \\
{ }^{1} \text { Department of Nature } \\
\text { Conservation, Faculty of } \\
\text { Natural Sciences, } \\
\text { Mangosuthu University of } \\
\text { Technology, Durban, } \\
\text { South Africa }\end{array}$} \\
\hline \multicolumn{2}{|c|}{$\begin{array}{l}{ }^{2} \text { Department of Curriculum } \\
\text { and Instructional Studies, } \\
\text { Faculty of Education, } \\
\text { University of Zululand, } \\
\text { Empangeni, South Africa }\end{array}$} \\
\hline \multicolumn{2}{|c|}{$\begin{array}{l}\text { Research Project Registration: } \\
\text { Project Number: } \\
\text { DEPT2016/104 }\end{array}$} \\
\hline \multicolumn{2}{|c|}{$\begin{array}{l}\text { Corresponding author: } \\
\text { Samantha Govender, } \\
\text { govendersa@unizulu.ac.za }\end{array}$} \\
\hline \multicolumn{2}{|c|}{$\begin{array}{l}\text { Dates: } \\
\text { Received: } 22 \text { June } 2020 \\
\text { Accepted: } 29 \text { Nov. } 2020 \\
\text { Published: } 25 \text { May } 2021\end{array}$} \\
\hline \multicolumn{2}{|c|}{$\begin{array}{l}\text { How to cite this article: } \\
\text { Pillay RP, Govender S. } \\
\text { Exploring the quality of } \\
\text { pre-service teachers' critical } \\
\text { analysis of cartoons within } \\
\text { environmental contexts in } \\
\text { the Life Sciences. J } \\
\text { transdiscipl res S Afr. } \\
\text { 2021;17(1), a863. https://doi. } \\
\text { org/10.4102/td.v17i1.863 }\end{array}$} \\
\hline \multicolumn{2}{|c|}{$\begin{array}{l}\text { Copyright: } \\
\text { ( 2021. The Authors. } \\
\text { Licensee: AOSIS. This work } \\
\text { is licensed under the } \\
\text { Creative Commons } \\
\text { Attribution License. }\end{array}$} \\
\hline \multicolumn{2}{|l|}{ Read online: } \\
\hline 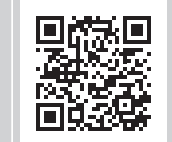 & $\begin{array}{l}\text { Scan this QR } \\
\text { code with your } \\
\text { smart phone or } \\
\text { mobile device } \\
\text { to read online. }\end{array}$ \\
\hline
\end{tabular}

Authors:

Auchendran P. Pillay

Affiliations:

${ }^{1}$ Department of Nature Conservation, Faculty of Mangosuthu University of Technology, Durban Faculty of Education, University of Zululand pangeni, South Afric

Project Number:

Corresponding author:

Samantha Govender,

Dates:

Accepted: 29 Nov. 2020

How to cite this article:

Pillay RP, Govender S.

pre-service teachers' critica

analysis of cartoons within

the Life Sciences.

2021;17(1), a863. https://doi.

Copyright:

(c) 2021. The Authors.

is licensed under the

Creative Commons

Attribution License.

\begin{abstract}
The world is presently facing a myriad of environmental challenges. One way to address these challenges is through the development of cognitive abilities to analyse environmental issues and respond to them appropriately. There are a number of approaches used in education processes to develop the cognitive abilities of students; one of them is the use of conceptual or reasoning cartoons. This article reports on an exploratory study of the quality of pre-service teachers' cognitive abilities in the analysis of three conceptual cartoons depicting real environmental challenges. The study was interpretivist in nature and followed a case study design. The participants were a convenient sample of students $(n=32)$ at year level three, at a Southern African residential university, doing a Life Science's teaching methods module. Students were required to analyse three environmental cartoons which they had not previously seen or discussed. The responses were coded according to the basic analytical steps of critical thinking and analysed qualitatively and quantitatively. The results showed that most responses were framed as descriptions of the cartoon rather than higher order analytical thinking; most students were unable to follow a sequence of analytical thinking; presentation of cognition was textual; and most pre-service teachers' responses were phrased in a way that made it seem as if they were not part of the environmental issue. It is recommended that Life Sciences' methodology pre-service teachers be categorically developed in analytical thinking of environmental issues, as they have a crucial role to play as future citizens.
\end{abstract}

Keywords: cartoons; environmental dimensions; sustainability; constructive learning; cognitive quality.

\section{Introduction}

Humankind is faced with a number of environmental issues. These issues are complex and include climate change, vector borne diseases, floods and droughts that threaten potable water supplies. ${ }^{1,2}$ Aside from natural causes, anthropogenic causes such as the disregard for environmental laws and unwise use of resources are contributing factors to the looming and existential situation faced by humankind. Education has been recognised as one of the strategies to address the environmental crises. ${ }^{3,4}$ However, the kind of education that is needed is one which develops analytical thinking and a holistic understanding of environmental issues and the possible strategies to address these issues and implement them.

In the Life Sciences and in the Environmental Education Curricula, learners are expected to develop critical analytical skills. The aim of education in the rapidly developing fields of science and technology is to actively engage students in lessons and to create ways to think critically to solve problems using creative alternates. ${ }^{5}$ There are a number of approaches used in education processes to develop cognitive abilities of students; one of them is the use of conceptual cartoons. The use of cartoons is twofold but not disjointed: (1) to develop analytical skills in students and (2) to hopefully prompt deeper introspection with the potential to lead to transformative life styles.

The main purpose of this research was to evaluate and explore the critical and analytical thinking abilities of pre-service student teachers in response to cartoons used in the Life Sciences within an environmental context. This study sought to explore the following question: What is the quality of pre-service teachers' answers to a critical analysis task of cartoons within environmental contexts in Life Sciences? 


\section{Literature review}

It is critical that the younger generation be made aware of their environment as they will face the repercussions of present-day challenges in the future. Thus, for them to actively participate in solving environmental problems in their daily lives, they would need to acquire adequate knowledge and a better understanding of environmental issues. This will thereby assist them to develop a positive attitude and acquire relevant skills enabling them to think scientifically and act purposely. ${ }^{6}$ Much effort is placed on the integration of environmental education in primary, secondary and tertiary education and how best to address this need. However, teaching environmental education, more especially those highly technical and particularly controversial issues, may be rather challenging. It is suggested that cartoons (a term used to include stand-alone illustrations, captioned or non-captioned, and short comic strip formats $)^{7}$ have a valuable contribution to make to learning. Thus, they may be considered as a potential teaching approach for environmental learning. Jamal, Ibrahim and Surif ${ }^{8}$ emphasised cartoons to be effective as they have the likelihood to increase creativity, innovativeness as well as student's understanding of concepts. Similarly, Van Wyk ${ }^{7}$ alluded to the point that the use of cartoons as a teaching strategy has significant benefits of promoting understanding, increasing attention towards learning, improving attitudes and developing divergent thinking. Cartoonists attack, provoke thought or provide a mirror and/or create awareness of behaviour on represented phenomenon through the convention of satire, contrasts and expression. ${ }^{9}$

In the research literature concept cartoons are defined as visual tools in which cartoon characters declare views about issues from daily life. ${ }^{10,11,12,13}$ In addition, cartoon characters enhance substantive conversation during classroom discussion amongst students, ${ }^{14}$ and short texts are used as dialogues to assist them to solve critical issues, ${ }^{15,16}$ which is particularly pertinent to environmental education. Notably, within this study, as the term 'concept cartoon' has been specifically copyrighted for commercial purposes. ${ }^{17}$ the general usage of concept cartoon is limited. However, the term 'cartoon' or 'reasoning cartoon' is used synonymously instead in this article to 'concept cartoons'.

Kabapinar ${ }^{18}$ reported from numerous case studies conducted on the use of concept cartoons in fourth- and fifth-grade primary school science learners in Turkey that concept cartoon teaching was effective in creating focused discussions where reasoning behind students' misconceptions could be uncovered, specifically through the use of teachers' thoughtprovoking questions. In addition, the cartoons also served as a remediation for misconceptions. Similarly, Balim, Nel and Evrekli ${ }^{19}$ in their research in Turkey used concept cartoons for seventh-grade science classes and revealed that concept cartoons impacted on students' enquiry learning skill perceptions by helping them to relate new knowledge to their existing experiences. Likewise, another Turkish study ${ }^{20}$ revealed that in using concept cartoons inquiry learning skills were developed while students attempted to validate their mental constructs and newly-acquired information by creating a conducive environment for cognitive conflict and substantive debate. Similar results were reported by Demirtas, Kiyici and Yigit $^{21}$ in eliciting student perspectives on concept cartoons. They concluded that concept cartoons encouraged reflective epistemic thinking and increased conceptual understanding.

Notably, several studies have examined the effects of cartoons from Turkey. Yet again, Eker and Karadeniz ${ }^{5}$ in Turkey investigated the effects of teaching practices using concept cartoon on students' achievement and knowledge retention. Findings indicated that the teaching practices using concept cartoons provided significant differences in increasing students' academic achievement and the level of knowledge retention in favour of the experimental group. Therefore, research evidence reveals that the use of visual tools, specifically concept cartoons in this case, creates a positive impact on student learning and encourages them to engage in the learning process. However, much of these studies in recent years seem to focus specifically on science education in the primary schools.

One of the key theoretical features of concept cartoons in science lessons is cognitive conflict and argumentation based on evidence. ${ }^{22,23}$ In other words, the actions of the characters or accompanying texts are in opposition promoting analysis, argumentation and decision-making. A study done by Naylor, Keogh and Downing ${ }^{24}$ in the United Kingdom provided evidence to support this theoretic feature of concept cartoons. Their study revealed that primary school students could easily co-construct arguments without the teacher's intervention or any prior training, particularly during science lessons. International research on concept cartoons support a key aspect of constructivist learning, that is, active learner involvement. $25,26,27,28$

Cartoons have a visual and immediate impact on students, irrespective of age or background, and trigger some response to the educational point being made. ${ }^{7}$ The active cognition can be enhanced and further boosts students' communication skills when they are working with their peers. ${ }^{29}$ A more recent study examined student's critical thinking and performances after implementing peer learning with concept cartoons. ${ }^{30}$ Their findings revealed significant results on students' critical thinking and performance, simply the students who engaged in peer learning through concept cartoons improved their performance. However, much of these studies referred to seem to focus on the knowledge and the active learning dynamics using cartoons. What is missing is the succinct link to environmental responsibility.

It is critical that environmental education and education for sustainable development strive beyond simply presenting learners with chunks of information about a given problem; instead, they must be taught the necessary skills that will equip them to apply the information in resolving the current environmental issues and to take responsible action. ${ }^{31}$ Redondo and Puelles ${ }^{32}$ have pointed out that environmental learning has not promoted pro-environmental behaviours as effectively as 
it has promoted pro-environmental knowledge and attitudes, noting that there is inconsistency in 'environmental attitudebehaviour gap'. They add that education should be more than a myopic approach of focusing on immediate learning objectives of curriculum content knowledge and liking of the subject. The focus of environmental education is necessary for changing people's opinions about the world and daily action through delivery of knowledge, providing a basis for attitude reflection and transformative action to fundamentally respond to environmental degradation. ${ }^{33}$ Environmental responsibility is not only collective but personal.

Dreyer and Loubser ${ }^{34}$ posited three principles that should underpin environmental learning, namely: (1) knowledge needed to address environmental problems and challenges; (2) the development of skills to study, solve and address environmental challenges; and (3) should include the affective domain, that is, the domains of attitudes, values and commitments to address environmental issues. In the context of this study, research evidence of principle (2) and (3) is the focus. The ability to analyse and creatively adapt to new situations is at the heart of critical thinking. ${ }^{35}$ Toledo, Yangco and Espinosa ${ }^{36}$ conducted a study in the Philippines with first year high school learners which focused on media cartoons as a teaching strategy specifically in Environmental Education. Their findings revealed that exposure to cartoons results in critical thinking and significantly better issue resolution skills on environmental education topics than the conventional approach. Their sample comprised of 6235 learners across 10 provinces in Thailand, and they further observed that learners who actively engaged themselves in media cartoon activities enabled them to take responsible actions and readily provide solutions to local and global environmental problems. Thus, the use of reasoning cartoons is an effective instructional tool that provides the necessary structure for learners to engage in high level inquiry and higher order thinking, and ultimately, it is hoped that responsible environmental action is the result. In addition, Kabapinar ${ }^{18}$ cited in Toledo et al., ${ }^{36}$ the cartoon technique is said to be efficient in teaching environmental problems and improving the quality of learning about the environment using a constructive structural approach. The goal of analysis is to answer questions by interpreting the information at a deeper level and providing actionable recommendations. This is different from a description of the physical actions being performed by the cartoon characters (Figure 1a and b) or by sentiments expressed (Figure 1c).

Collectively much of the literature seems to focus on the potential benefits of reasoning cartoons within an international context, specifically in science education in the primary school classroom settings. This is mainly because of cartoon concepts in teaching and learning being used to attract the interest of primary school learners in science subjects. By simply acknowledging the efficacy, visual effectiveness and appeal of reasoning cartoons, it presents an opportunity for it to be used as a constructivist and powerful tool in enhancing environmental education more especially amongst students in institutions of higher learning.
A constructivist theory underpins the study reported in this article. The basis of constructivism is that knowledge gained and understanding are broadened through active construction and reconstruction of mental frameworks and through making valid connections between new and existing knowledge. ${ }^{37}$ Learning within the constructivist theoretical framework is characterised as an active and learner-centred process. Dreyer and Loubser ${ }^{34}$ stated that learners should be active participants in the learning context in environmental education. Further, they pointed out that environmental learning should involve critical thinking skills which include content knowledge, procedural knowledge such as steps in analysis as well as doing analysis and commenting on different perspectives. Critical thinking then encompasses employing knowledge leading to awareness and self-regulation in decision-making. ${ }^{38}$ However, Casiraghi ${ }^{38}$ alluded to some logical flow in critical thinking, although this may not always be the case, that is, understanding the issue, seeking and knowing how to choose the most effective solution, showing motivation and displaying attitude of permanence in resolution of issues. ${ }^{38}$ The process of analysis consists of breaking knowledge down into its parts,

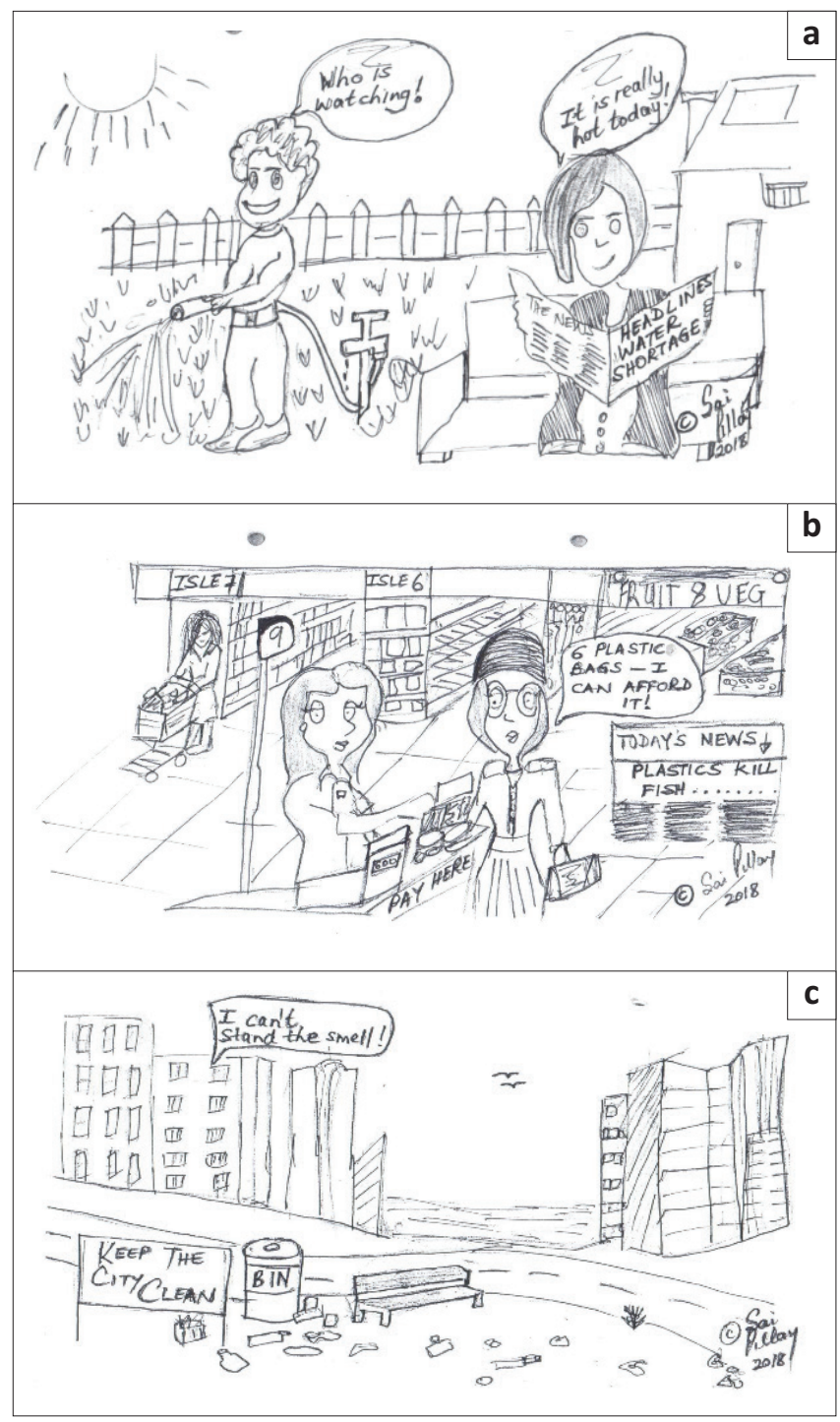

Source: Sai Seolin Pillay (cartoons originally drawn for the study)

FIGURE 1: (a) Cartoon one, (b) cartoon two and (c) cartoon three. 


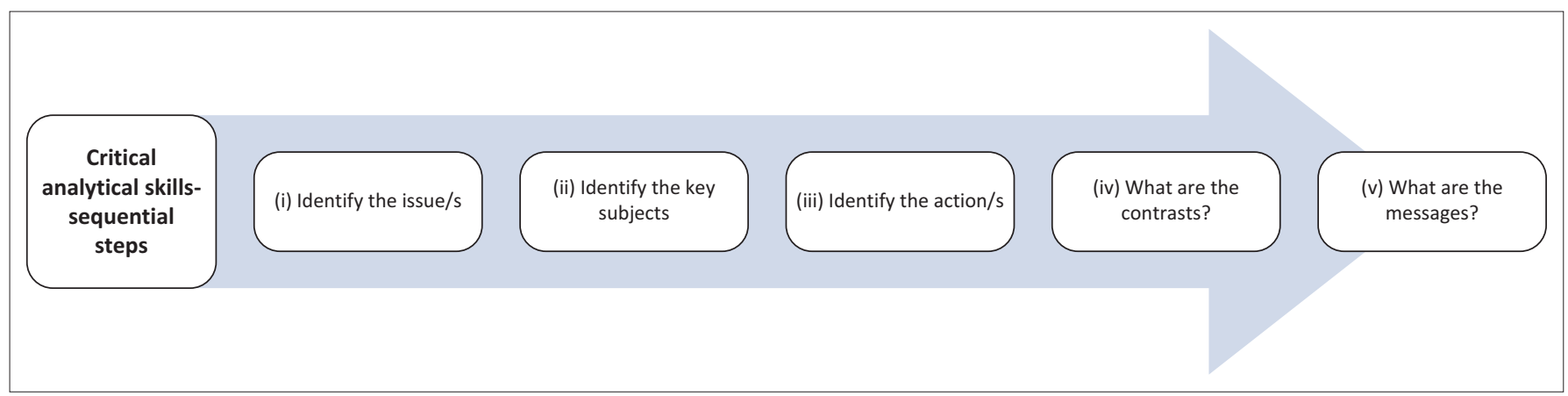

Source: Adapted from Lutrin B, Pincus M. English handbook and study guide. Johannesburg: Berlut Books; 2015

FIGURE 2: Sequential steps for critical analysis.

thinking about how the parts relate to the overall picture through interpreting, comparing, contrasting, differentiating, organising, attributing, making inferences and synthesising. ${ }^{37,39}$ Analysis involves higher order thinking moving beyond clinical descriptions. Lutrin and Pincus ${ }^{40}$ highlighted the basic sequential steps specifically regarding analytical skills related to cartoons (see Figure 2).

These sequential steps were used by the researchers in this study to analyse student responses. The cartoons in this study were used as an intentional cognitive prompt to initiate critical analysis.

\section{Methodology \\ Research paradigm and design}

This research is anchored within an interpretivist paradigm. An interpretivist paradigm is based on understanding the response of participants within a rich analytical context rather than using post-positivist objectivity. ${ }^{41} \mathrm{~A}$ case study research design was used because of its suitability for indepth study through gathering data of the cognition of the participants, ${ }^{41}$ in response to the specific task. In this study, the aim was to elicit the responses of the participants to three reasoning cartoons within an environmental context and then analyse the responses using a tool for analytical skills. In this article, an analysis of cartoons one, two and three are presented (Figure 1). Qualitative and quantitative data were generated through coded categories and thick descriptions, and descriptive statistics, respectively.

\section{Participants and settings}

In the South African context, environmental topics have been included in the Life Sciences/Biology and Natural Sciences higher education curricula. The data were collected from year level three undergraduate students registered for a semester module in Life Sciences/Natural Sciences methodology at a South African university. The students were preparing for a teaching career focusing on Life Sciences/Biology and Natural Sciences. Convenience sampling was used as the research was part of the scholarship of teaching and learning, and the module was taught by one of the researchers. The students were given the cartoons at the beginning of the module without any deliberate teaching or recapitulation of critical analytical skills and without any discussions on the topical environmental issues depicted in the cartoons. The assumption was that at tertiary year level three, Science students would have had acquired some level of critical analytical skills through their education. The students were given an hour to respond individually to the cartoons in a lecture venue, without any prior discussion with fellow students. Anonymity was maintained, as personal details such as student name and number were not asked for. In total, 32 students (12 males and 20 females) participated in the study.

\section{Data collection and analysis}

The participants were given an open-ended task to do on their own. The only given instruction was: Kindly analyse cartoons one, two and three. The cartoons were original as they were designed by the researcher. The cartoons were not necessarily humorous but attempted to portray real-life contexts with an integrated environmental focus. Dreyer and Loubser $^{34}$ pointed out that environmental learning should be authentic, that is, should be based on real-life contexts. A brief description of each cartoon (Figure 1) is given below.

\section{Cartoon one}

Depicted the wastage of water during a period of water shortage. The cartoon brought out the message of the negation of moral conscience (Who is watching?) by deliberate wastage of a character through a contrast of the newspaper headline: Water shortage.

\section{Cartoon two}

Depicted the buying of plastic bags by a character based on the personal economic affordability. The cartoon contrasted the behaviour with a newspaper headline: Plastics kill fish.

\section{Cartoon three}

Depicted the lack of concern for environmental messages such as 'Keep the city clean'. The contradictory behaviour is shown by littering close to a bin and with high levels of pollution in a populated neighbourhood expressed in a speech bubble.

The analytical framework used for the study was that of Lutrin and Pincus ${ }^{40}$ as represented in Figure 2. This framework encompasses the different tenets of critical thinking as expounded in the literature review and is 
pertinent to cartoon analysis. Both a qualitative approach and a quantitative approach were used in the analysis. Qualitative analysis involved content analysis using coding and identification according to the analytical framework (as presented in the results). The key elements for framing the analysis in the study were: Cognition (higher order thinking versus description; presentation of analysis; logical steps of analysis) and environmental responsibility (first person [we/ us] vs. third person [they/people]). The predetermined categories were identified within the coded data, and these are supported with verbatim responses from participants. Quantitative analysis was done through numerical counts of the overall responses in the coded data categories, thus generating descriptive statistics. In interpreting the descriptive statistics, the authors raise awareness that in total, 96 responses were expected (32 participants responding to three cartoons).

\section{Results}

The results are presented in two parts, namely cognition and environmental aspects. Descriptive statistics of the analysis and quotations of students' responses are presented in the analysis and results.

\section{Cognition}

Given the nature of critical analytical tasks, amongst others, three aspects of cognition can be identified. These are higher order thinking, presentation of the analysis and the logical steps used in analysis. The results of these three aspects of the analytical framework are presented in Tables 1, 2 and 3 respectively.

\section{Higher order thinking}

The results show that a far higher percentage (87.3\%) of the students gave a description of the cartoons rather than showing higher order thinking in their analysis of the cartoons. The following quotations are examples of descriptions of the cartoons:

'In this cartoon it shows that in the news plastic kill fish, so this lady wanted 6 plastics.' (C2, female 13, pre-service teacher participant, 2018)

'Cartoon shows pollution where people litter the environment. They throw rubbish outside the bin and that causes a smell ...' (C3, female 13, pre-service teacher participant, 2018)

'It is during the day, there is sunlight and the father is watering the grass, taking care of the grass or nature while not knowing that he's wasting water because the little girl next to him is complaining about the day is hot ...' (C1, female 16, pre-service teacher participant, 2018)

'In this cartoon they are showing us that people are doing water pollution because today's news is saying that plastics kill fish and fish are not found anywhere but they live only in water.' (C2, male 5, pre-service teacher participant, 2018)

Although a comparison for each student across the three cartoons was not done, the examples quoted show that these
TABLE 1: Cognition: Higher order thinking versus description.

\begin{tabular}{lcccccccc}
\hline Variable & \multicolumn{3}{c}{ Higher order thinking } & & \multicolumn{3}{c}{ Description } \\
\cline { 2 - 4 } \cline { 7 - 9 } & Female & Male & Total & & Female & Male & Total \\
\hline Cartoon one & 4 & 1 & 5 & & 16 & 11 & 27 \\
Cartoon two & 2 & 3 & 5 & & 18 & 9 & 27 \\
Cartoon three & - & 2 & 2 & & 19 & 10 & 29 \\
\hline Total $(n)$ & 6 & 6 & 12 & & 53 & 30 & 83 \\
Total $(\%)$ & 10.1 & 16.6 & 12.6 & & 89.8 & 83.3 & 87.3 \\
\hline
\end{tabular}

Note: Males: Cartoon 1, 2 and 3, $n=12$; Females: Cartoon 1 and 2, $n=20$; Cartoon 3, $n=19$; Total responses $=95$.

TABLE 2: Logical steps of analysis (issue, key subjects, the action, the contrasts, message(s) in context/broader message - destruction to planet earth).

\begin{tabular}{|c|c|c|c|c|c|c|}
\hline \multirow[t]{2}{*}{ Variable } & \multicolumn{3}{|c|}{ Logical } & \multicolumn{3}{|c|}{ Random } \\
\hline & Male & Female & Total & Male & Female & Total \\
\hline Cartoon one & $4 \dagger$ & $5 *$ & 9 & $8 \dagger$ & $15 *$ & 23 \\
\hline Cartoon two & $4 \dagger$ & $3 *$ & 7 & $8 \dagger$ & $17 末$ & 25 \\
\hline Cartoon three & $3 \dagger$ & $2 \S$ & 5 & $9 \dagger$ & $17 \S$ & 26 \\
\hline Total $(n)$ & 11 & 10 & 21 & 25 & 49 & 74 \\
\hline Total (\%) & 30.5 & 16.9 & 22.1 & 69.4 & 83.1 & 77.8 \\
\hline
\end{tabular}

$\dagger, n=12 ; \uparrow, n=20 ; \S, n=19$.

TABLE 3: Environmental responsibility: First person (we/us) versus third person (they/people).

\begin{tabular}{lcccccccc}
\hline Variable & \multicolumn{3}{c}{ First person } & & \multicolumn{3}{c}{ Third person } \\
\cline { 2 - 3 } \cline { 7 - 9 } & Male & Female & Total & & Male & Female & Total \\
\hline Cartoon one & $3 \dagger$ & $3 \$$ & 6 & & $9 \dagger$ & $17 *$ & 26 \\
Cartoon two & $3 \dagger$ & $5 \$$ & 8 & & $9 \dagger$ & $15 *$ & 24 \\
Cartoon three & $4 \dagger$ & $3 \S$ & 7 & & $8 \dagger$ & $16 \S$ & 24 \\
\hline Total $(n)$ & 10 & 11 & 21 & & 26 & 48 & 74 \\
Total $(\%)$ & 27.8 & 18.6 & 22.1 & & 72.2 & 81.3 & 77.9 \\
\hline
\end{tabular}

$\dagger, n=12 ; \dagger, n=20 ; \S, n=19$.

students provided descriptions for the reasoning cartoons instead of analysing the cartoons. In other words, primarily there was a translation of the visual into a textual description.

The quotations which follow show higher order thinking in the analysis of the reasoning cartoons. The comparison of the responses to Cartoon one (C1) as shown in the quotations of females (2), (3) and (9) show higher order thinking. Female (2) generalises the message to education, female (3) personalises the message to the individuals of the broader community and female (9) analyses the cartoon within a biological framework by suggesting a time when plants should be watered, thus suggesting a solution to wasting water. Male (9) identifies the problem of water wastage and further broadens thinking by commenting on the selfish nature of the action and the implications for survival:

'Cartoon 1 tells us about the shortage of water in the world. It shows how people waste water. It also tells us how to conserve our nature by saving water. The man in the cartoon wastes more water and he doesn't care for the future generation. This shows that people in the world are still not educated about the importance of saving water. People need to be educated about how to save water.' (C1, female 2, pre-service teacher participant, 2018)

'The message portrayed in this cartoon is that in our homes we know about the shortage of water but we still reluctant to act in a way that will save water, because we still have it in our communities or our tanks, we think that it is something that will affect some people not us, because we have not experienced it yet.' (C1, female 3, pre-service teacher participant, 2018) 
'The guy that is watering is actually wrong because he thinks that no one is watching, while it is wrong to water plants in the midday when the sun is too hot. He is just wasting water ... The correct time to water is in the morning before the sun comes out. Doing so will make the plants absorb water.' (C1, female 9, preservice teacher participant, 2018)

'The cartoon is showing that people do things that affect them just because there is no one who is seeing them. For instance, there is a shortage of water but the man is busy using the water for irrigation. The man is egocentric he only thinks about his garden not about the many lives that depends on the water that he is wasting.' (C1, male 9, pre-service teacher participant, 2018)

\section{Presentation of analysis}

All the responses of the students to the reasoning cartoons were presented in the text format. Other tools for analysis, for example, mind maps or concept maps, were not used. The students were given space for their responses but without prescribing the form of the response. None of the responses showed physical evidence of student cognition processes, for example, making any notes, marks or shading on the cartoon itself, as evidence of some form of analysis or contrast of attitudes, actions or messages. This was not given as an instruction, that is, to shade or not shade. Physical evidence would have provided greater insight to the quality of student cognition.

Applying analytical skills requires basic sequential steps as alluded to by Lutrin and Pincus ${ }^{40}$ (Figure 2). These steps were not taught to the students by the lecturer prior to the task in this module. Analytically, these logical steps emphasise the message or messages of the cartoon and enhance its argument or objective.

Overall, a high percentage $(77.8 \%)$ of the students were random in the presentation of their analysis rather than following logical steps. In the quotations that follow, the numeric reference is used to show the logical steps in analysing the cartoon. The following are examples of students' complete responses showing the logical steps of analysis:

'This cartoon shows a woman (2) whose been doing some grocery shopping and requires 6 plastic bags for small items because she can afford them not that she wants to use them. And the headline emphasizes that plastics kill animals (3) because human beings don't restore or recycle (4) but they dump them everywhere and cause damage to fish and other living things (5).' (C2, female 14, pre-service teacher participant, 2018)

'Cartoon is all about ignorance of the people (1)(2). The bin is well located and it is visible and written, but the citizens just dump (3) and pollute where ever they went (4) and now it is affecting the nearby residences with the smell (5).' (C3, male 12, pre-service teacher participant, 2018)

'In this cartoon they are telling us that we must not pollute the environment (1), as you can see citizens (2) are complaining that they can't stand the smell, it may be harmful to them. It may cause asthma. There is a board saying keep the city clean which emphasizes that citizens are not listening they fail to pick up their waste material (3). and throw it into the bin instead they throw it on the ground (4). So, this pollution of air causes the city to have a bad smell and it will be dangerous to people to get polluted air which will cause diseases (5), so keep your environment clean in to live a healthy life (5).' (C3, male 5, preservice teacher participant, 2018)

The following are examples of students' complete responses with steps omitted or with no sequence in the analysis or where students provided a general comment. The responses of females (15) and (16) are examples of where steps of cartoon analysis have been omitted. A case in point is that in both quotations no categorical reference is made to the contrast between environmental messages and behaviours. These contrasts were clearly evident in cartoon one (Figure 1a).

'Shortage of water (1). Irrigation, water from the taps/clean water, shouldn't be used for irrigation, to save water for other uses (5). Who is watching - it is not supposed to be done or practised.' (C1, female 15, pre-service teacher participant, 2018)

'It is during the day, there is sunlight and the father (2) is watering the grass, taking care of the grass or nature while not knowing that he's wasting water because the little girl (2) next to him is complaining about the day being hot.' (C1, female 16 , pre-service teacher participant, 2018)

'First person that says - who is watching (2), I think this person is watering his vegetable but I think the message that they are trying to show us is that we should not waste water by doing unnecessary thing or using a hose pipe (5). The person on the right-hand side reads the newspaper that warns about the shortage of water (5) and it is important to read the newspaper just to know what is happening around us.' (C1, female 19, preservice teacher participant, 2018)

'People can't keep their place clean (2) and tend to complain about it; forgetting that it is their fault the place is not clean. Because if we don't take care of our environment, the environment will not take care of us back (6).' (C3, male 11, preservice teacher participant, 2018)

'The cheapness or the affordability of the plastic bags is causing harm in the aquatic environment and the plastics are then dumped at the rivers and coastlines because of its abundance (5).' (C2, male 12, pre-service teacher participant, 2018)

Comparing both set of responses, it is evident that some students used logical steps in their analysis (C3, Female 14; C3, Male 5; and C3, Male 12), while other students (C2, Male 12; C1, Female 16) omitted some aspects or did not follow a logical sequence.

\section{Environmental aspects}

Responding to environmental issues require individual change and collective responsibility. However, a significant observation in this study is the way in which student responses were framed. There were responses which showed personal accountability by referring to we (including the self as part of the accountability and responsibility of action), while in other responses students seemingly excluded themselves from the issue by using the third person (they or people) in their descriptions - 22 per cent of the responses were framed using a first-person response. The quotations of Females 1 and 3 and Male 6 shows reference to inclusive responsibility and accountability. The following quotes are 
examples of the first person being used to analyse the cartoons:

' $[W e]$ must be proud of the city and must keep the city clean.' (C3, female 1, pre-service teacher participant, 2018)

'The message portrayed in this cartoon is that in our homes we know about the shortage of water but we still reluctant to act in a way that will save water ...' (C1, female 3 , pre-service teacher participant, 2018)

'We have to conserve our nature so that we maintain mutual relationship.' (C2, male 4, pre-service teacher participant, 2018)

'Sometime we fail to use our common sense about our earth we live in and it brings bad effects to us as well.' (C3, male 6, preservice teacher participant, 2018)

Seventy-seven per cent of the responses showed a third person response. The following quotes are examples of the third person use in the analysis of the reasoning cartoons. The quotations of Male 9 show consistency in a third-person response for all three cartoons:

'So, if you want to buy some items e.g. cooking oil, it is better to use bags not plastics.' ( $\mathrm{C} 2$, female 1 , pre-service teacher participant, 2018)

'So the best thing the citizens or society can do is to reserve what they still have and not waste the remaining water instead use it wisely.' (C1, female 9, pre-service teacher participant, 2018)

'The cartoon is showing that people do things that affect them just because there is no one who is seeing them.' (C1, male 9, preservice teacher participant, 2018)

'The cartoon is showing that people do unnecessary things just because they have money.' (C2, male 9, pre-service teacher participant, 2018)

'The cartoon shows that people are not aware of that everything they do has consequences.' (C3, male 9, pre-service teacher participant, 2018)

It can be inferred from the results that a far higher percentage of students consciously or unconsciously do not perceive that they are part of environmental issues. Rather, they seem to perceive the responsibility and accountability of the environmental issues as related to others.

\section{Discussion}

The purpose of this study was to explore the cognitive quality of student's responses to a critical analysis task of reasoning cartoons within environmental contexts of real challenges in the Life Sciences. Cartoons have the potential to trigger the neuro-cognitive framework of students. ${ }^{42}$ Critical analysis according to Bloom' Taxonomy is placed as a higher order cognitive skill which is more than providing a clinical description or statements of the context. ${ }^{37,39}$ In this study, it was found that more students provided descriptions of the cartoons instead of higher order analysis. In the real-world analysis of environmental issues, rather than descriptions of them, are required if strategies to address these issues are to be developed and implemented. The intention of using reasoning cartoons is to challenge students to think on a higher level. ${ }^{17}$
While analysis as a cognitive process can be interpreted as an abstract phenomenon, evidence of communication of this analysis can take many forms. In this study, students' responses for all the concept cartoons took a textual form of representation. There were no responses which took other forms, for example, a mind map or a table using key headings for analysis. Van $\mathrm{Wyk}^{7}$ pointed out that cartoons usually exaggerate certain objects, characters or actions that focus on a learning point. The findings show that no student had made any marks on the cartoons to highlight key texts, actions or contrasts that were exaggerated. A limitation of this study was that there was no follow-up interview post the analysis to establish possible reasons why students did not do this.

Cartoons provide visual information in the form of caricatures, drawings and texts and use specific directives, such as shape, size, symbolism, and grammatical conventions, such as question marks, exclamation marks and contrasts in actions to emphasise messages. ${ }^{36,43}$ The literature suggests that analysis as a cognitive skill to analyse cartoons has definite and logical sequences to make sense of the meanings and to critically reflect on these meanings. ${ }^{40}$ All three cartoons had key messages that were emphasised. The findings show that most students did not use a sequential framework for their critical analysis; rather, there were various initiation points such as the key messages or the characters or the actions. While not forcing a dominant scientific approach over free thinking to cartoon analysis, it is likely that application of a more structured cognitive framework to their critical analysis would have enhanced the quality of the analysis rather than providing a clinical description of the visual representation, as most students in this study had provided.

Environmental responsibility and accountability have been accorded to all sectors of the community - industry, political constituencies and at all levels (local, national and international) as well as to individual citizens as actors. Behavioural transformation does not preclude individuals. Webb $^{17}$ pointed out that reasoning cartoons may not be epigrammatic but can be a visual representation of identifiable real-life contexts. The cartoons in this study provided a medium for self-reflection and accountability. In this study, a significant finding was that a high percentage of students $(77.9 \%)$ excluded their individual citizenship responsibility from the anthropological domain through references in the third person such as 'they' and 'people'. A significantly lower percentage of students identified with their individual citizenship responsibility by referring to 'we' in their analysis. While the cartoons in this study provided recognisable real-life contexts, the responses show that the student analysis assumed an academic analysis underplaying personal accountability, responsibility and ownership of the anthropogenic impact on the environment.

\section{Conclusion}

The research question in this study was: what is the cognitive quality of Life Sciences student's critical analytical responses to an analysis task of cartoons within 
environmental contexts of real-life challenges? Firstly, the results of the study show that the majority of the students in this study largely provided descriptions of the recognisable contexts of the cartoon rather than the application of higher order thinking. The instruction for the task categorically required students to analyse the cartoons. Secondly, in attempting to identify aspects of logical analysis in all 96 responses (higher order thinking and in descriptions), most student responses were random than logical. Thirdly, environmental responsibility and accountability is personal and collective. In this study, most students phrased their responses in the third person (they/people) giving a perception that environmental problems exist outside of their being. The task in this study was more than an academic exercise. The intention of reallife contexts in the cartoons was to elicit deeper understanding of environmental issues through the application of a higher order skill, namely analysis. The implication of the results in this study is that students' analytical skills are inadequate to understand the complexity of environmental problems which require greater insight to appropriately respond to in action. In addition, distancing ownership of environmental problems is more likely to make the response to these environmental issues less urgent and non-meaningful. It is recommended that firstly, students' analytical skills be deliberately focused on and be intentionally developed through opportunities for application within the context of real-life reasoning cartoons. It will also be useful if lecturers can reiterate sequential steps for analysis at the beginning of modules rather than taking it for granted as it may have implications for student performance in assessment. Secondly, a conscious effort be made at higher education institutions to raise environmental issues in a relevant personalised way, as citizens of Earth rather than as purely intellectual, theoretical and academic frameworks.

\section{Acknowledgements}

\section{Competing interests}

The authors declare that they have no financial or personal relationships that may have inappropriately influenced them in writing this research article.

\section{Authors' contributions}

R.P.P. and S.G. contributed equally to this work.

\section{Ethical considerations}

Ethical clearance for the study was obtained from the University's Research Ethics Committee and the necessary ethical procedures were followed (Ethical Clearance Number: UZREC 1711110-030).

\section{Funding information}

This research received no specific grant from any funding agency in the public, commercial or not-for-profit sectors.

\section{Data availability}

The authors confirm that the data supporting the findings of this study are available within the article.

\section{Disclaimer}

The views and opinions expressed in this article are those of the authors and do not necessarily reflect the official policy or position of any agency of the authors.

\section{References}

1. Leicht A, Combes B, Byun WJ, Agbedahin AV. From agenda 21 to target 4.7: The development of education for sustainable development. In: Leicht A, Heiss J, Byun WJ, editors. Issues and trends in education for sustainable development. Paris: UNESCO, 2018; p. 25-38.

2. Saha GK. Climate change: Man and environment. New Delhi: Daya Publishing House; 2012.

3. Loubser CP. Environmental education in the non-formal sector. In: Loubser CP, editor. Environmental education and education for sustainability. Pretoria: Van Schaik Publishers, 2016; p. 179-186.

4. Nasibulina A. Education for sustainable development and environmental ethics. Procedia Soc Behav Sci. 2015;214:1077-1082. https://doi.org/10.1016/ j.sbspro.2015.11.708

5. Eker $\mathrm{C}$, Karadeniz $\mathrm{O}$. The effects of educational practice with cartoons on learning outcomes. Int J Humanit Soc Sci. 2014;4(14):223-234.

6. Tilbury D, Keogh A, Leighton A, Kent J. A national review of environmental education and its contribution to sustainability in Canberra. Canberra: Australian Government Department of the Environment and Heritage and Australian Research Institute in Education for Sustainability (ARIES), 2005; p. 1-5.

7. Van Wyk MM. The use of cartoons as a teaching tool to enhance student learning in economics education. J Soc Sci. 2011;26(2):117-130. https://doi.org/10.1080/ 09718923.2011.11892888

8. Jamal SNB, Ibrahim NHB, Surif JB. Concept cartoon in problem-based learning: A systematic literature review analysis. J Technol Sci Educ. 2019;9(1):51-58. https:// doi.org/10.3926/jotse.542

9. Samuel AK. Satirizing the Nigerian climate: Multimodal discourse analysis of selected political cartoons from TELL newsmagazine. Asian Res J Arts Soc Sci. 2017;3(4):1-10. https://doi.org/10.9734/ARJASS/2017/33327

10. Keogh B, Naylor S. Science goes underground. Adults Learn. 1999;10(5):3-6.

11. Naylor S, Keogh B. Concept cartoons: What have we learnt?. J Turkish Sci Educ. 2013;10(1):1-10.

12. Keogh B, Naylor S, Wilson C. Concept cartoons: A new perspective on physics education. Phys Educ. 1998;33(4):219-224. https://doi.org/10.1088/00319120/33/4/009

13. Sexton M, Gervasoni A, Brandenburg R. Using a concept cartoon to gain insight into children's calculation strategies. Aust Prim Math Classroom. 2009;14(4): 24-28.

14. Morris M, Merritt M, Fairclough S, Birrell N, Howitt C. Trialling concept cartoons in early childhood teaching and learning of science. Teach Sci. 2007;53(2):42-45.

15. Chin C, Teou LY. Formative assessment: Using concept cartoon, pupils' drawings, and group discussions to tackle children's ideas about biological inheritance. J Bio Educ. 2010;44(3):108-115. http://doi.org/10.1080/00219266.2010.9656206

16. Naylor S, Downing B, Keogh B. An empirical study of argumentation in primary science, using concept cartoons as the stimulus. Paper presented at 3rd European Science Education Research Association Conference; 2001 Aug; Thessaloniki, Greece.

17. Webb L. The use of cartoons as a tool to support teacher ownership of mathematics curriculum change. Afr J Res Math Sci Technol Educ. 2015;19(1): 57-68. https://doi.org/10.1080/10288457.2015.1012905

18. Kabapinar F. Effectiveness of teaching via concept cartoons from the point of view of constructivist approach. Educ Sci Theor Pract. 2005;5(1):135-146.

19. Balim AG, Inel D, Evrekli E. The effect of use of concept cartoons in science education on students' academic achievements and inquiry learning skill perceptions. Prim Educ. 2008;7(1):188-202.

20. Evrekli E, Inel D, Balim AG. A research on the effects of using concept cartoons and mind maps in science education. Electron J Sci Math Educ. 2011;5(2):58-85.

21. Demirtas Z, Kiyici FB, Yigit EA. Concept cartoons in science education: Availability and students' opinions about the cartoons. Energy Education Science and Technology Part B: Social and Educational Studies, 2012; p. 861-865.

22. Jiménez-Aleixandre MP, Bugallo Rodríguez A, Duschl RA. "Doing the lesson" or "doing science": Argument in high school genetics. Sci Educ. 2000;84(6):757-792. https://doi.org/10.1002/1098-237X(200011)84:6\%3C757::AID-SCE5\%3E3. $0 . C O ; 2-\mathrm{F}$

23. Keogh B, Naylor S, De Boo M, Feasey R. Formative assessment using concept cartoons: Initial teacher training in the UK. In: Behrendt H, Dahncke H, Duit R, et al. editors. Research in science education - Past, present, and future. Hingham, MA: Kluwer Academic Publishers; 2001; p. 137-142. https://doi.org/10.1007/0306-47639-8_18 
24. Naylor S, Keogh B, Downing B. Argumentation and primary science. Res Sci Educ. 2007;37(1):17-39. https://doi.org/10.1007/s11165-005-9002-5

25. Bandiera $M$, Bruno C. Active/cooperative learning in schools. J Biol Educ 2006;40(3):130-134. https://doi.org/10.1080/00219266.2006.9656030

26. Chambers S, Andre T. Gender, prior knowledge, interest, and experience in electricity and conceptual change text manipulations in learning about direct current. J Res Sci Teach. 1997;34(2):107-123. https://doi.org/10.1002/(SICI)10982736(199702)34:2\%3C107::AID-TEA2\%3E3.0.CO;2-X

27. Keogh B, Naylor S, Downing B. Children's interactions in the classroom: Argumentation in primary science. 4th European Science Education Research Association conference; Aug 19-23. Noordwijkerhout, 2003; p. 137-142.

28. Naylor S, Downing B, Keogh B. An empirical study of argumentation in primary science, using concept cartoons as the stimulus. 3rd European Science Education Research Association conference. Thessaloniki; 2001.

29. Shurkin J. Science and culture: Cartoons to better communicative science. Sci Cult. 2015;112(38):11741-11742. https://doi.org/10.1073/pnas.1515144112

30. Yin KY, Fitzgerald R. Peer learning with concept Cartoons enhance critical thinking and performance in secondary school economics. J Econ Econ Educ Res. 2017;18(1):1-13.

31. Rieckmann M. Learning to transform the world: Key competencies in education for sustainable development. In: Leicht A, Heiss J, Byun WJ, editors. Issues and trends in education for sustainable development. Paris: UNESCO 2018; p. 39-59.

32. Redondo I, Puelles M. The connection between environmental attitude - Behavior gap and other individual inconsistencies: A call for strengthening self-contro International. Res Geogr Environ Educ. 2017;26(2):107-120. https://doi.org/ 10.1080/10382046.2016.1235361
33. Gao Y. To study the relationship between environmental education and environmental behavior based on environmental attitude. Ekoloji. 2018;27(106):627-634.

34. Dreyer J, Loubser CP. Curriculum development, teaching and learning for the environment. In: Loubser CP, editor. Environmental education and education for sustainability. Pretoria: Van Schaik Publishers, 2016; p. 145-175.

35. Changwong K, Sukkamart A, Sisan B. Critical thinking skill development: Analysis of a new learning management model for Thai high schools. J Int Stud. 2018;11(2):37-48. https://doi.org/10.14254/2071-8330.2018/11-2/3

36. Toledo AM, Yangco RT, Espinosa AA. Media cartoons: Effects on issue resolution in environmental education. Int Electron J Environ Educ. 2014;4(1):19-51. https:// doi.org/10.18497/iejee-green.99250

37. Killen R. Teaching strategies for quality teaching and learning. Cape Town: Juta and Company; 2015.

38. Casiraghi R. Fundaments of critical thinking evaluation in high education. J Educ Hum Develop. 2017;6(3):98-103. https://doi.org/10.15640/jehd.v6n3a11

39. Soozandehfar SMA, Adeli BAl. A critical appraisal of Bloom's taxonomy. Am Res Engl Lit [serial online]. 2016 [cited 2019 Jun 25];2:1-9. Available from: https:// pdfs.semanticscholar.org

40. Lutrin B, Pincus M. English handbook and study guide. Johannesburg: Berlut Books; 2015.

41. Bertram C, Christiansen I. Understanding research: An introduction to reading research. Pretoria: Van Schaik Publishers; 2019.

42. Lodhi MA, Ibrar SN, Shamim M, Naz S. Linguistic analysis of selected TV cartoons and its impact on language learning. Int J Engl Linguist. 2018;8(5):247-258. https://doi.org/10.5539/ijel.v8n5p247

43. Köse EO. Effects of cartoons on students' achievement and attitudes in biology. Kastamonu Educ J. 2013;21(3):931-944. 